\title{
Mozgásprogram hatása a has- és hátizmok izomerejére, különös tekintettel az idôs korosztályra - Core-training
}

\section{ÖSSZEFOGLALÁS:}

Bevezetés: A világ fejlett országaiban, így Magyarországon is a népesség öregedést mutat, mely többek között kihat az egészségügyi ágensekre is.

Célkitǔzések: Fő célkitűzésünk volt felmérni, hogyan változik a középkorú és idősödő nők gerincszakaszainak mozgásterjedelme, törzsizmainak ereje és alsó végtag izmok flexibilitása egy 16 héten át tartó heti két alkalommal szervezett 60 perces Core-tréning hatására.

Eredmények: $\mathrm{Az}$ adatokat a Microsoft Office 2003 és a Microsoft Office Excel 2007 programokkal elemeztük, leíró statisztika módszerei közül az átlag és a szórás. Gerinc szakaszainak mozgásterjedelem-vizsgálata: flexió, extenzió, laterálflexió, rotáció; Törzs izmainak statikus izomerő mérése: hasizom, hátizom, laterálflexió Plank helyzetben; Nyújtás vizsgálata: Hermstring és m. Qadriceps izmokban. Az átlagok azt mutatják, hogy az előés utómérések alsó végtag izmainak nyújtása kivételével minden eredmény javul.

Következtetések: Összességében elmondható, hogy egy 16 héten át tartó heti két alkalommal szervezett 60 perces Core-tréning pozitív hatással van a 45-74 éves nók mozgásterjedelmére, törzsizom statikus erőre. Az alsó végtag meghatározó izmainak flexibilitására jobban kell ügyelnünk a mozgásprogram folyamán.

Kulcsszavak: Core-training, gerincmobilizáció, törzsizmok ereje, alsó végtag izmainak nyújtása, 45-54 éves nők

\section{ABSTRACT:}

Introduction: In the developed countries of the world, including Hungary, the population is aging, it also affects health agents.

Aims: Main aims was to examine, how the mobility of the spine, trunk strength and flexibility of lower bad change in middle-aged and aging woman by the 16 -months long Core-training program twice a minute per 60 week.

Results: Data were analysed by Microsoft office 2003 and Microsoft Office Excel 2007 programes for Windows with Descriptive statistic Mean \pm SD. Spinal Range of motion flexion, extension, later- alflexion and rotation; Static Strength of Trunk: abdominal, back, lateralflexion in Plank state; Flexibility: Hermstring and musculus Quadriceps. According to exeption of flexibility of lower bed every results were imroved between pre- and post tests. Conclusions: We can say, that the 60-minute Core training was organized twice a week for 16 weeks have positive effect on 45-74 years woman , we can take better care of flexibility of lower leg in the program.

Key words: Core-training, spine mobility, trunk muscles stength, lower bed flexibility, 45-54 years woman

\section{Bevezetés}

A világ fejlett országaiban, így Magyarországon is a népesség öregedést mutat (Economic Co-operation and Development, 2009). A Központi Statisztikai Hivatal korfájának adatai mutatják a 60 év feletti népesség koreloszlását. A korfán alul helyezkednek el a legfiatalabbak, majd felfelé haladva az idősebb korosztályok. A halványabb rész fedi le a 60 év feletti lakosságot 258.830 fó, a népesség 26,45\%-a (1. ábra). A fenti statisztikákból látható kutatási témánk időszerüsége (Széman, 2008).

A testmozgás hiánya a legtöbb időskori betegség okozója, ide tartoznak a mozgásszervrendszeri elváltozások és a motoros képességek leépülése. Az izomerő-csökkenés mértéke a fekvés, az inaktivitás következtében egy hét alatt elérheti az 5-20\%-ot is, mely különösen az antigravitációs izmokban lehet jelentős mértékü (Mészárosné, 2004; 2008). Ez az önellátási képességek csökkenéséhez vezethet. Nehéz a lépcsőn való járás, a felülés-felállás, valamint megnövekedhet az ele-
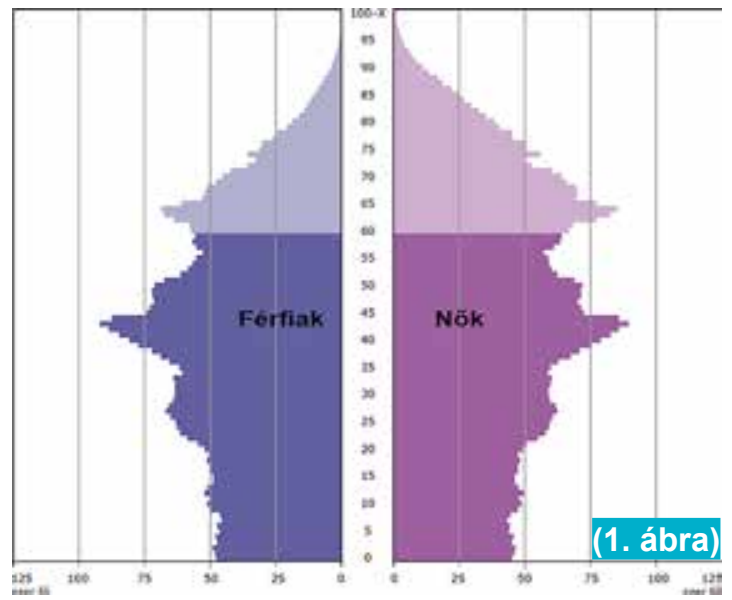

sések és csonttörések száma. A megelőzésében gondoskodni kell az ingergazdag környezetről, izotóniás és izometriás testgyakorlatokról, esetleg a passzív átmozgatásról. Két előtanulmányban is olvashatunk az Egerben élő 55 év feletti felnőttek égészségtudatos magatartásáról (Vécseyné és mtsai, 2007; Vécseyné, Plachy és Bog-

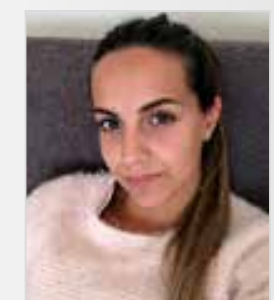

Szerzō:

FARKAS TÜNDE

IV. éves hallgató, Miskolci Egyetem Egészségügyi Kar tundefarkas101@gmail.com Tudományos tevékenysége: végzős gyógytornászhallgató Főbb kutatási területei: mozgásterápia, idősek, prevenció, egészségmegőrzés

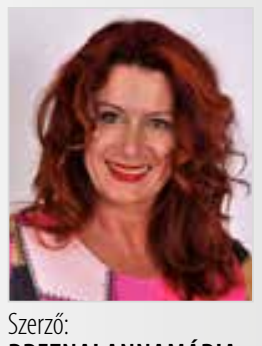

BREZNAI ANNAMÁRIA

Mesteroktató

Érdeklődési kör: primer prevenció, rehabilitáció, mentálhigiéné, palliatív ellátás

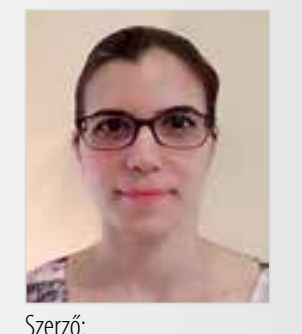

Szerzó:

LEBENSZKYNÉ SZABÓ TÜNDE Mesteroktató

Szívügye a gerinc egészségének védelme. Szabadidejében zenehallgatás, zenés mozgásformák végzése, kézilabda

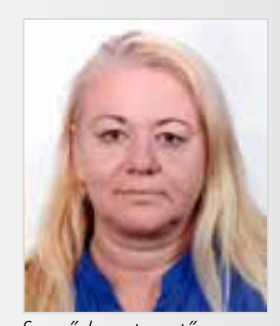

Szerzo" / rovatvezetô:

DR. K. PLACHY JUDIT Munkahely: Miskolci Egyetem Egészségüigyi Kar Fizioterápiás Intézeti Tanszék - adjunktus efkplachy@uni-miskolc.hu Érdeklődési kör: fizikai rekreációs foglalkozások tartása minden korosztály, leginkább a nyugdijas lakosság számára. 
nár, 2008), itt is bebizonyosodott, hogy a rendszeres testmozgást végző idősek egészségesebbek, fittebbek és kevesebbet esnek el, mint az inaktív társaik.

Miután ebben a kutatásban a középkorúak és az öregedők kapnak szerepet, nézzük meg a WHO szerinti felosztást: a 45-59 évest középkorúnak, a 60-74 évest öregedőnek, a 75-90 évest öregnek, és a 90 év feletti embert aggnak nevezi ( $W H O, 2008)$.

Fő célkitűzésünk volt felmérni, hogyan változik az öregedő és idős nők gerincszakaszainak mozgásterjedelme, törzsizmainak ereje és alsó végtag izmok flexibilitása egy 16 héten át tartó heti két alkalommal szervezett 60 perces Core-tréning hatására.

\section{Módszerek}

A vizsgálatokat a sajóládi Közösségi Ház nyugdíjasklubjában végeztük, a résztvevők önként beleegyezésével. A tornaprogram ugyanitt került megtartásra. A programra 15 fő jelentkezett, akik mind nyugdíjasok, 56-70 év közöttiek, nálunk az (Méletkor=60,74). A kritériumok a következők: magas vérnyomás, súlyos osteoporosis, akut légúti megbetegedés, pacemaker. A vizsgálatot 2019. június 9-én és 10-én végeztem el, a program pedig 2019. júnis 11-től 2019. október 29-ig tartott. A visszamérést 2019. november 5-én és 8-án végeztük el. A tornákra heti kétszer került sor 60 percben. Minden alkalom egy előzőleg összeállított tematika alapján zajlott le.

Core-training: Gerincünknek, mely a testünk tartóoszlopa és a törzsünk tengelye, két mechanikailag elengedhetetlen tulajdonsággal kell rendelkezni a funkcionálisan meg- felelő mozgások kivitelezése miatt. Abban a pillanatban azonban, hogy a legcsekélyebb elmozdulást végezzük a térben, gerincünknek folyamatosan stabil alapot kell biztosítania, harmonikusan, koordináltan, az egyes gerincszakaszoknak egymástól eltéró irányokba kell elmozdulnia, azaz dinamikus stabilitás szükséges, melyet a csont- és izomrendszer koordinált együttmúködése biztosít, ebben szerepet játszanak a szalagok is. Különböző helytelen testtartási formák alakulhatnak ki, ezeket okozhatja például fájdalom - antalgiás tartás, izomdisbalance, ízületi problémák. Ha kialakul a helytelen testtartás, akkor a súlyvonal helyzete elmozdul, a gerinc görbületei is megváltoznak. Ennek eredményeként fokozódhat a fájdalom, sérülések és az esések kockázata, és romolhat az egyensúly is (Szabó, 2018).

\section{Mérés}

Néztünk Decimális életkort, testtömeget, testmagasságot és BMI-t számoltunk.

\section{Gerinc szakaszainak mozgásterjedelem-vizsgálata:}

- Gerinc flexiós mozgásterjedelem-vizsgálata: a páciens állásban, lábai összezárva. Előrehajol, a boka irányába, térdeit nem hajlítja. Mérjük a 3-as ujj és a talaj közötti távolságot $(\mathrm{cm})$

- Gerinc extensiós mozgásterjedelem-vizsgálata: a páciens hason fekvésben, kezei a teste mellett. Törzsemelés, medence nem emelkedhet. Mérjük a fossa jugularis és a talaj közötti távolságot $(\mathrm{cm})$
Gerinc laterálflexiós mozgásterjedelem-vizsgálata: a páciens falnak háttal áll, a törzs kitérésének kivédése érdekében. Karjait lecsúsztatja a combján, felváltva. Mérjük a 3. ujj és a talaj közötti távolságot. Az eredménynek a testmagasság 10\%ának kell lennie és egyformának (cm)

- Gerinc rotációs mozgásterjedelem-vizsgálata: a páciens állásban helyezkedik el, ajtófélfánál. Kérem, hogy forduljon el oldalra, közben a medence rögzítve, vállakat ne húzza előre. Mindkét oldalon elvégzem a vizsgálatot. Mérjük az acromion és a fal közötti távolságot $(\mathrm{cm})$

\section{Törzs izmainak statikus izomerőmérése:}

- Hasizomerő vizsgálata statikusan: a páciens háton fekvő helyzetben, lábai talpra húzva, kezei a combján. Mennyi ideig tudja megtartani (s)

- Hátizomerő vizsgálata statikusan: a páciens hason fekvésben, lábai kis terpeszben, kezek a tarkón, kispárna a has alá a lumbalis lordosis fokozódásának kivédésére. Emelje meg a törzsét a bordák alsó részéig, lapockákat zárja. Az arc végig lefelé tekint. Mennyi ideig tudja megtartani (s)

- Oldalt Plank helyzet vizsgálata statikusan: a páciens oldalt fekvésben, alul lévő karja alkartámaszban, felül lévő kar nyújtva a törzsön, lábak a törzs folytatásában. Emelje meg a medencét, törzset, az arc előretekint. Mennyi ideig tudja megtartani (s)

\section{Irodalomjegyzék}

Howell, LA. (2008): Lisa Howell's Perfect Form Core Stability Course, The Perfect Point Book, Sydney

Kopkáné, P. J. (2015): A rendszeres fizikai aktivitás hatása az idős kori függetlenség megőrzésére 60 év fölötti nők esetében: randomizált kontrollált kísérlet. [Phd értekezés]. Testnevelési Egyetem Sporttudományok Doktori Iskola, 1-116.

Kloubec, J. A. (2010): Pilates for improvement of muscle endurance, flexibility, balance and posture. Journal of Strength \& Conditional Researches, 24:(3) 661-667.

Organization for Economic Co-operation and Development (2008): OECD.StatExtracts, http://stats.oecd.org/viewhtml.aspxqueryname $=18155 \&$ querytype $=$ view\&lang=en

Shephard, R. J. (1998): Az öregedés és az edzés. Ford. Tóth Kálmán. http://www.szamosz.hu/irodalmak/Az\%20oregedes\%20es\%20 az\% 20edzes.pdf [2019.12.17.] (Eredeti mü: Aging and exercise. In: Encyclopedia of Sports Medicine and Science.)

Szabó, A. (2018): Elesés-kockázat és frailty mérés idősek körében QTUG eszközzel. In: Osteológiai Közlemények, 1-2. sz. p. 47-51.
Somhegyi, A. (2015): Mozgás, testtartás, tánc. Mindennapi gerincvédelem. In: Sokszínű egészségtudatosság: Értsd, csináld, szeresd! Budapest, SpringMed, $295 \mathrm{p}$.

Szémán, Zs. (2008): Ki az idős? - Az öregedés különböző szempontjai. In: Esély, 19. évf., 3. sz. p. 3-15.

Vécseyné, K. M. - Olvasztóné, B. Zs. - Gangl, J. - Bognár, J. (2007): The health-conscious behavior of people over 55: a preliminary study focusing on gender, marital status, income and educational level, Kalokagathia, 3-4: 42-51.

Vécseyné, K. M. - Plachy, J. - Bognár, J. (2008): A felnőttek egészséges, aktív életmódja - Összehasonlító tanulmány a fiatal felnőttek és idős korosztály életmódjáról, rendszeres fizikai aktivitásáról. In: Eszterházy Károly Főiskola tudományos közleményei. Új sorozat, 35. kötet. p. 107-115.

WHO (2008): 2008-2013 Action plan for the global strategy for the prevention and control of noncommunicable diseases. Geneva. http://www.who.int/nmh/Actionplan-PC-NCD-2008.pdf

WHO (2010): Global Recommendations on Physical Activity for Health. Közread. A Library Cataloguing-in-Publication Data, 60 p. ISBN 978924159999 


\section{Nyújtás vizsgálata:}

Hemstring nyújthatóság mérése: a páciens háton fekvésben, karok a test mellett nyújtva. A nem vizsgált oldali lábat talpra húzza. Emelje nyújtva a vizsgált lábat, addig a pontig, amíg a térd kezd hajolni $(\mathrm{cm})$

m. Quadratus lumborum nyújthatóság vizsgálat: a páciens oldalt fekvő helyzetben, alul lévő karja alkartámaszban, lábai a törzs folytatásában. Kérem, hogy ejtse le a törzsét lazán. Mértük a 12-es borda és a talaj közötti távolságot $(\mathrm{cm})$. Az adatokat a Microsoft Office 2003 és a Microsoft Office Excel 2007 programokkal elemeztük, leíró statisztika módszerei közül az átlag és a szórás.

\section{Eredmények}

A Decimális éltkor

Méletkor $(60,74 \pm 1,79 S D)$;

BMIelö $(M=28,626 \pm 4,626 S D)$;

BMIutó $(28,48 \pm 4,229)$.

Gerinc szakaszainak mozgásterjedelem-mérése: A gerinc bal oldali rotációjának kivételével minden mért teszt jobb lett a gerincbántalomban nem szenvedők estében (2. ábra).

Izomerőmérések eredményei: Itt mind a négy mért izomerő javult az utómérések idejére (3. ábra).

Nyújtás vizsgálata: Két izom, mind a két oldali Hemstring és Quadrátus lumbórum nyújthatóságának mérése a program elején és végén. Minden eredméy romlott (4.,5. ábra).

\section{Összegzés}

Az öregedésből adódó betegségek, mint a szívés érrendszeri betegségek legtöbb esetben progresszív lefolyásúak. Ezt a folyamatot le lehet lassítani a rendszeres fizikai aktivitás által egy 16 héten át tartó heti két alkalommal szervezett 60 perces Core-tréning hatására. (Shepard, 1998).

A WHO (2010) ajánlása alapján idős korban is elkezdhető minimum 3 alkalommal 30 perces közepes intenzitású testmozgás. Lehet változatos fajtájú edzésprogramokat alkalmazni, de fontos az intenzitás fokozatos növelése (Kloubec, 201O, Somhegyi, 2018).

A mi kutatásunkban is kiemelt helyen szerepel a prevenció, ezért a testtartást meghatározó, a gerinc stabilitást és mobilitást biztosító gerincoszlop mozgásterjedelmének mérése. Megállapítottuk, hogy melyik résztvevőnek van fokozottabb gerincproblémája, így rájuk nagyobb odafigyeléssel dolgoztunk.

Következő tesztünkben négy, a testtartást meghatározó törzsizom statikus erejét elemeztük, ahol minden esetben fejlődés következett be az elő- és utómérések között. Azt viszont el kell ismernünk, hogy nagyobb hangsúlyt kell fordítani az alsó végtagok izmainak nyújtására.

Összességében elmondható, hogy egy 16 héten át tartó heti két alkalommal szervezett 60 perces Core-tréning pozitív hatással van az 55-54 éves idős nők mozgásterjedelmére, törzsizom statikus erőre. Az alsó végtag meghatározó izmainak flexibilitására jobban kell ügyelnünk.
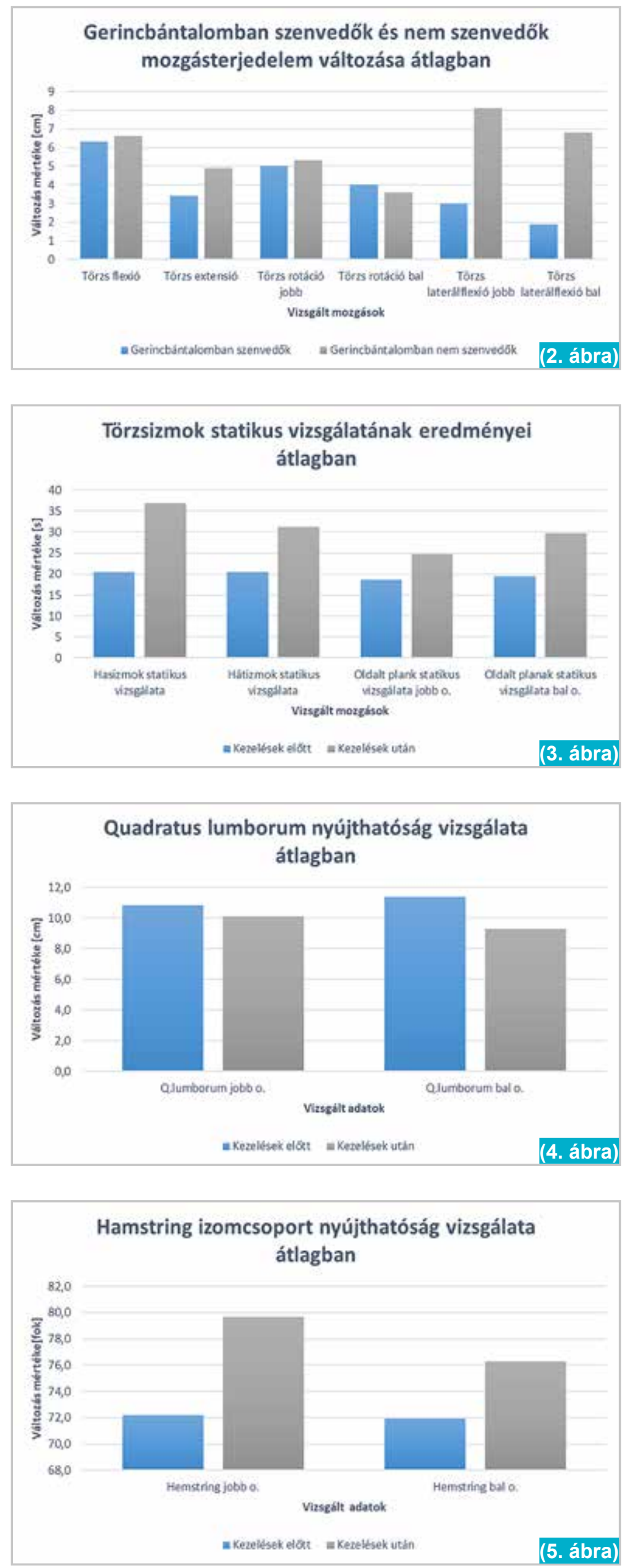